\title{
CASE PRESENTATION OF EMERGING SECONDER SARCOPENIA AFTER SEPSIS ATTACKS IN INTENSIVE CARE UNIT
}

Turkish Journal of Geriatrics

DOI: 10.31086/tjgeri.2019.97

2019;22 (2):228-232

\section{• Esra ÇAKIR ${ }^{1}$ iD \\ - Belgin AKAN¹ iD \\ - Esra SARI ${ }^{1}$ iD \\ • Berkay KÜÇÜK ${ }^{1}$ iD \\ - Işıl ÖZKOÇAK}

\section{Abstract}

Sarcopenia is defined as decreased muscle mass, muscle strength and physical performance. In geriatric patients, secondary sarcopenia may also develop due to underlying diseases in addition to the known primary sarcopenia. Computed tomography and magnetic resonance imaging are the gold standard to calculate skeletal muscle index in the diagnosis of sarcopenia. The diagnostic approach is easier in mobilized, outpatient and hospitalized patient. However, it is difficult to perform a gold standard computed tomography and magnetic resonance imaging for the diagnosis of sarcopenia and evaluate muscle strength and physical performance in patients who cannot be mobilized and stay in the intensive care unit. In this case report, we aimed to present the case in order to raise the awareness of clinicians considering the difficulty of application of diagnostic criteria of secondary sarcopenia in the course of prolonged intensive care unit hospitalization and difficulty of performing computed tomography and the lack of consensus on prevention and treatment of sarcopenia.

Keywords: Intensive Care Unit; Psoas Muscle; Sarcopenia; Muscle, Skeletal
CORRESPONDANCE

\section{Esra ÇAKIR}

Health Sciences University, Ankara

Numune Education and Research Hospital,

Anesthesiology and Clinical of Critical Care,

Ankara, Turkey.

Phone: +903125085175

e-mail: pavulonmouse@hotmail.com

\section{Received: 22/02/2019}

Accepted: 22/03/2019

Health Sciences University, Ankara Numune Education and Research Hospital, Anesthesiology and Clinical of Critical Care, Ankara, Turkey.
OLGU SUNUMU

\section{YOĞUN BAKIM ÜNITESINDE SEPSIS ATAKLARI SONRASI SEKONDER SARKOPENI GELIŞEN OLGUNUN SUNUMU}

$\ddot{O}_{z}$

Sarkopeni azalmış kas kitlesi, kas gücü ve fiziksel performans olarak tanımlanmaktadır. Geriatrik hastalarda bilinen primer sarkopeniye ek olarak altta yatan hastalıklara bağlı sekonder sarkopeni de gelişebilir. Sarkopeni tanısında özellikle iskelet kas indeksi hesaplamak için bilgisayarlı tomografi ve manyetik rezonans görüntüleme altın standarttır. Mobilize olabilen, ayaktan ve servis hastalarında tanısal yaklaşım daha kolaydır. Ancak yoğun bakım ünitesinde yatan ve mobilize olamayan hastalarda sarkopeni tanısı için altın bilgisayarlı tomografi ve manyetik rezonans görüntüleme yapmak ve kas gücü ile fiziksel performans değerlendirmek zordur. Bizim rapor ettiğimiz olguyu, uzamış yoğun bakım ünitesi yatışı sürecinde sekonder sarkopeninin tanı kriterlerinin uygulanmasında ve bilgisayarlı tomografi yapılmasındaki zorluğu, sarkopeninin önlem ve tedavisinde fikir birliği olmaması nedeniyle klinisyenlerin farkındalığını artırmak için sunmayı amaçladık.

Anahtar sözcükler: Yoğun Bakım Ünitesi; Psoas kası; Sarkopeni; İskelet Kası. 


\section{INTRODUCTION}

Sarcopenia (decreased muscle mass and function) is characterized by cachexia, negative protein and energy balance, multi-organ syndrome, anorexia and decreased physical function (1). Sarcopenia was first described by Rosenberg in 1989 to draw attention to geriatric syndromes associated with decreased muscle mass with aging (2). The prevalence of sarcopenia generally ranges between $6-22 \%$ over the age of 65 years (3). It was first defined as primary sarcopenia characterized by decreased muscle mass in the elderly. Then, secondary sarcopenia, which is defined by three main pathogenic mechanisms (inflammatory activity, malnutrition and physical activity disorder), was described. Despite the widely used definition of primary sarcopenia, clinical trials for secondary sarcopenia are still insufficient (4). In particular,there are studies conducted on chronic diseases or in certain hospitalized groups. Although computed tomography (CT) and magnetic resonance imaging (MRI) are the gold standard in the diagnosis of sarcopenia, it is a difficult diagnostic procedure due to high cost and difficulty in clinical practice. Instead, dual-energy $\mathrm{X}$-ray absorptiometry (DXA) and bioelectrical impedance analysis (BIA) are more easily applicable for diagnostic purposes (5). There is little awareness about the prognostic value of sarcopenia in patients with surgery, trauma and cancer, not only in elderly patients who are in intensive care unit (ICU) (6). In this article, we aimed to present a 65-year-old man with chronic lymphocytic leukemia (CLL) in remission who was hospitalized in the ICU for a long time period and diagnosed of sarcopenia by using CT evaluation. As a result, this case would draw attention to the development of secondary sarcopenia in ICU.

\section{CASE}

A 65-year-old male patient in remission of CLL for the last 1 year was admitted to the emergency department due to fever $\left(39^{\circ} \mathrm{C}\right)$ and respiratory distress. His physical examination revealed bilateral rales, blurred consciousness, and drowsiness. Additionally, the Glasgow Coma Scale score was 4. Heart rate was 106/minute, respiratory rate was 48/minute, and oxygen saturation was $84 \%$ in room air. The patient was intubated due to respiratory failure. The blood pressure was $80 / 60 \mathrm{mmHg}$. Therefore, he was immediately treated with serum saline infusion. Subsequently, appropriate intravenous fluid administration and inotropic treatment were started. Furthermore, bilateral infiltration was detected on chest X-ray examination. Respiratory acidosis was detected in blood gas examination. He had normal liver and kidney functions. Leukopenia (506 cells $/ \mathrm{mm}^{3}$ ) and increased C-reactive protein (CRP) (342 mg/L) (our hospital reference levels: 0-5 $\mathrm{mg} / \mathrm{L}$ ) were identified. Eventually, he was transferred to the ICU with prediagnosis of pneumonia, sepsis and CLL relapse. Cranial CT scan was performed due to lethargy and confusion, andrelieved normal findings. After admission to ICU, whole body fluid cultures were obtained, and then initial empirical intravenous (IV) antibiotics (ceftriaxone, vancomycin, and acyclovir) were started. Streptococcus pneumoniasusceptible to ceftriaxone was yielded in both cerebrospinal fluid and blood culture. Vancomycin and acyclovir treatments were discontinued after culture results. Ceftriaxone treatment was continued until negative control cultures. In hematological evaluation, $\mathrm{CCL}$ relapse was not considered in peripheral smear and bone marrow examination. The patient was extubated on the $19^{\text {th }}$ day of hospitalization and started full enteral nutrition on the 25th day. The patient's calorie intake was regulated as $20-25 \mathrm{kcal} /$ $\mathrm{kg} /$ day and protein intake was regulated to have 1.5 $\mathrm{g} / \mathrm{kg}$ body (7). On the $26^{\text {th }}$ day of hospitalization, the patient had fever $\left(39.3^{\circ} \mathrm{C}\right)$, respiratory distress, lethargy, bilateral rales, respiratory acidosis, leukocytosis (22.400 cells/mm³) and CRP: $285 \mathrm{mg} /$ Lwhich were indicated sepsis and pneumonia. Therefore, respiratory support was initiatedwith mechanical ventilator (MV). Subsequently, Acinetobacter baumannii was detected in the blood culture, and colistin was administered for 14 days 
for nosocomial pneumonia and sepsis. Respiratory physiotherapy was started and continued during hospitalization. In the follow-up, tracheostomy was applied because of extubation failure, and percutaneous endoscopic gastrostomy (PEG) was applied to maintain his nutrition.

On the $53^{\text {rd }}$ day of hospitalization, sarcopenia was suspected because of failure in weaning from MV, low body mass index $\left(17,4 \mathrm{~kg} / \mathrm{m}^{2}\right.$, cut-off $<20 \mathrm{~kg} / \mathrm{m}^{2}$ ), low muscle mass, low muscle strength and low physical performance. Subsequently, CT, which was recognized the gold standard diagnostic method and the first of three diagnostic criteria for sarcopenia, was used to evaluate the skeletal muscle index (SMI) (8). Since, the patient's state of consciousness was not suitable, an informed consent was obtained from his relatives before CT examination. Image was obtained to calculate SMI from caudal region of the third lumbar (L3) vertebrae to evaluate the right and left psoas muscle, which was the best determinative area of muscle mass in abdominal CT. Thus, SMI was calculated as a total psoas muscle area divided by height squared (Figure 1). Also, total muscle area (TMA, in $\mathrm{cm}^{2}$ ) is measured at $L 3$ using a semi-automatic segmentation software (Figure 2). The TMA was then normalized to obtain $\mathrm{SMI}$ in $\mathrm{cm}^{2} / \mathrm{m}^{2}$ (2). The patient's SMI was found to be $48.6 \mathrm{~cm} 2 / \mathrm{m} 2$ (cut-off $<52.4$ for sarcopenia in male) according to the formula $\mathrm{SMI}=$ (skeletal muscle mass/body mass) $\times 100$, which was used by Janssen et al. to define sarcopenia (9). The psoas muscle area (PMA), which was the core muscle that reflects the condition of skeletal muscle in the whole body, was calculated as 12.1 (cut-off $<16.8$ for sarcopenia) in our patient (10). Low muscle strength and low physical performance could not be evaluated with diagnostic tests for two other criteria of sarcopenia in the patient who was not able to orientate and cooperate. The patient was considered to have low muscle strength and low physical performance because of inadequate respiratory effort and poor mobility of the extremities. In the laboratory analysis hypoalbuminemia $(1.8 \mathrm{~g} / \mathrm{dL})$ and concurrent
CRP (4 mg/L) associated with sarcopenia were normal (to exclude inflammatory causes) (1). Nutritional supplementation (daily caloric intake of $30 \mathrm{kcal} / \mathrm{kg}$, protein intake of $2 \mathrm{~g} / \mathrm{kg}$ body weight, vitamin $D$ replacement) and exercise program were started for the patient who was diagnosed sarcopenia secondary to infection $(11,12)$. The patient was discharged with tracheostomy with MV support and PEG on the $115^{\text {th }}$ day of hospitalization. The relatives of the patient provided written informed consent before all procedures.

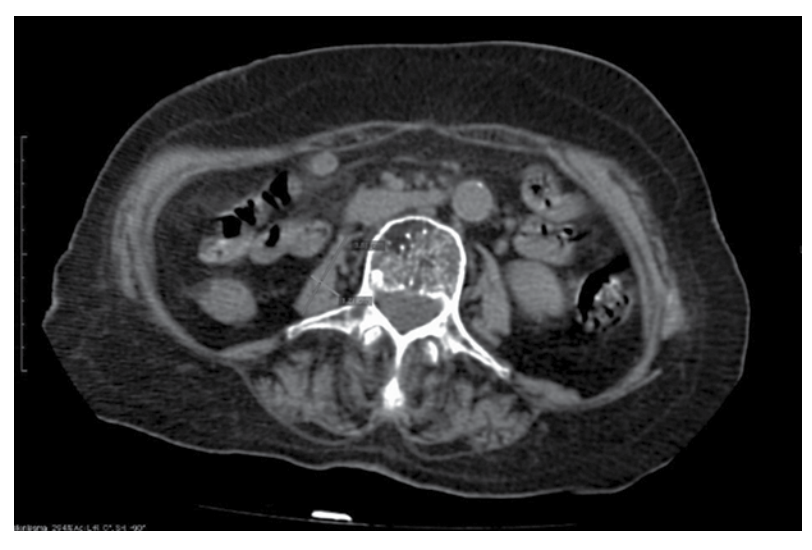

Figure 1. Psoas muscle lumbar 3 section with computed tomography for calculation of skeletal muscle index.

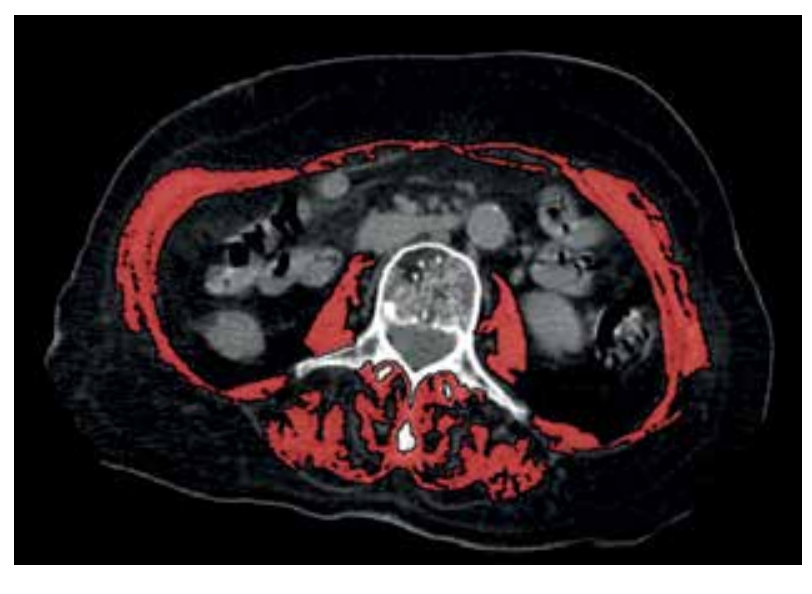

Figure 2. Total muscle area of lumbar 3 section obtained using semi-automatic segmentation software. 


\section{DISCUSSION}

Sarcopenia is defined as age-related reduction in skeletal muscle mass. Its incidence is $29 \%$ in elderly people and $33 \%$ in patients required long-term palliative care. However, its incidence is not clear in ICU (5). The pathophysiology of sarcopenia is multifactorial. Decreased calorie intake, muscle fiber denervation, intracellular oxidative stress, cytokinesis, endocrine and metabolic factors as well as genetic predisposition may cause sarcopenia. Difficulty in weaning of the patients from MV support is associated with prolongation of hospitalization, and acute and chronic weakness of the muscles $(1,5)$.

Nevertheless, the relationship between neuromuscular acquired weakness and secondary sarcopenia is not fully known. In addition, it may not be possible to prevent muscle loss due to increased catabolism in the first period. Although proper protein intake and exercise have been used successfully to treat weakness in older patients (primary sarcopenia), it is possible to fail in severe catabolic status as in our patient, even if standard treatment is applied in sarcopenia due to secondary conditions $(5,13)$. Studies on sarcopenia in patients admitted to the ICU are lacking. Therefore, secondary sarcopenia should be kept in mind for the patients who are cared in the ICU for a long-term period(11). If sarcopenia is overlooked, and not diagnosed and treated early in time, it is associated with increased morbidity and mortality $(5,13)$.

Muscle mass (i), muscle strength (ii) and physical performance (iii) should be evaluated to diagnose sarcopenia based on modern definitions. Screening for sarcopenia is recommended in both elderly patients and patients with significant reduction in physical function (5). The European Working Group on Sarcopenia in Older People (EWGSOP) proposed three stages of sarcopenia: presarcopenia (presence of one criterion), sarcopenia (two criteria), and severe sarcopenia (three criteria) (8). There are some difficulties in assessing ICU patients from a diagnostic standpoint. If patients with sarcopenia are orientated and cooperated enough related to age and disease status, muscle strength and physical performance can be evaluated. As in our patient, central nervous system disease and prolonged respiratory support without sedation and weakness can be considered as indicators of low muscle strength and low physical performance $(5,13)$. Imaging methods used to measure muscle mass are ultrasound (US), MRI, CT, DXA, and BIA. Ultrasonography, DXA and BIA are easy techniques to use for the diagnosis (13). However, the CT and MRI, which are the gold standard methods to evaluate muscle mass ofpatients in ICU, are difficult to perform and expensive (5). However, it is thought that the patient should be evaluated with CT for a more accurate diagnosis of muscle mass (13). It has been shown that cross sectional muscle surface at the third L3 best reflects total skeletal muscle mass determined by CT or MRI. In practice, TMA is measured at L3 using a semi-automatic segmentation software on a dedicated post-treatment station. TMA is then normalized to stature (using height ${ }^{2}$ in $\mathrm{m}^{2}$ ) to obtain the SMI in $\mathrm{cm}^{2} / \mathrm{m}^{2}(2,9)$. The cut-off value of sarcopenia in men is $<52.4$, while the cut-off value of sarcopenia in women is declared to be $<38.5$ (1.9). Our patient SMI was found to be $48.6 \mathrm{~cm}^{2}$ / $\mathrm{m}^{2}$ (for men) according to the SMI. The PMA, which was the core muscle that reflects the condition of skeletal muscle in the whole body, was calculated as 12.1 (cut-off <16.8 for sarcopenia) in our patient (10). The patient who was considered to have sarcopenia based on the diagnostic criteria, should receive proper treatment and exercise. However, despite proper medical treatment, exercise, protein and energy support, MV support and length of hospitalization of the patient were prolonged due to secondary sarcopenia. Therefore, some criteria and tools should be used to assess the morbidity and mortality of critically ill patients during the hospitalization. Once sarcopenia suspected, it should be diagnosed early, and supportive treatment should be started immediately. (14). As in our patient, sepsis is a risk factor for prolonged 
ventilator and acquired neuromuscular weakness, which may be a common problem of patientsin ICU (15). We aimed to present our case to ensure that secondary sarcopenia shouldbe considered and draw attention to diagnostic difficulties in patients with prolonged ventilation and duration of hospitalization in ICU despite the treatment of primary disease and proper physical therapy, energy

\section{REFERENCES}

1. Hilmi M, Jouinot A, Burns R, et al. Body composition and sarcopenia: the next-generation of personalized oncology and pharmacology? Pharmacol Ther 2019 Apr;196:135-59 (PMID:30521882).

2. Epidemiologic and methodologic problems in determining nutritional status of older persons. Proceedings of a conference. Albuquerque, New Mexico, October 19-21, 1988. Am J Clin Nutr 1989;50(5 Suppl):1121-235. (PMID:2816807).

3. Dent E, Morley JE, Cruz-Jentoft AJ, et al. International Clinical Practice Guidelines for Sarcopenia (ICFSR): Screening, Diagnosis and Management. J Nutr Health Aging 2018;22(10):1148-61. (PMID:30498820).

4. Barone M, Viggiani MT, Anelli MG, et al. Sarcopenia in patients with rheumatic diseases: prevalence and associated risk factors. J Clin Med 2018;7(12). pii: E504. (PMID:30513782).

5. Marty E, Liu Y, Samuel A, Or O, Lane J. A review of sarcopenia: Enhancing awareness of an increasingly prevalent disease. Bone 2017;105:276-86. (PMID:28931495).

6. Toptas M, Yalcin M, Akkoc l, et al. The relation between sarcopenia and mortality in patients at intensive care unit. Biomed Res Int 2018 Feb 12;2018:5263208. (PMID:29789798)

7. Singer $P, B$ laser $A R$, Berger MM, et al. ESPEN guideline on clinical nutrition in the intensive care unit. Clin Nutr 2018. pii: S0261-5614(18)32432-4. (PMID:30348463).

8. Cruz-Jentoft AJ, Bahat G, Bauer J, et al. Writing Group for the European Working Group on Sarcopenia in Older People 2 (EWGSOP2), and the Extended Group for EWGSOP2. Sarcopenia: revised European consensus on definition and diagnosis. Age Ageing and protein support. There is a need for further advanced studies on the frequency of sarcopenia, its progress during the hospitalization, proper nutritional requirement, normal SMI attainment, duration of hospitalization and effect on mortality especially in patients in ICU.

\section{Conflict of interest}

None.

\section{9;48(1):16-31. (PMID:30312372).}

9. Janssen I, Heymsfield SB, Ross R. Low relative skeletal muscle mass (sarcopenia) in older persons is associated with functional impairment and physical disability. J Am Geriatr Soc 2002;50(5):889-96. (PMID:12028177).

10. Zuckerman J, Ades M, Mullie L, et al. Psoas muscle area and length of stay in older adults undergoing cardiac operations. Ann Thorac Surg 2017;103(5):1498504. (PMID:27863730).

11. Kizilarslanoglu MC, Kuyumcu ME, Yesil Y, Halil M. Sarcopenia in critically ill patients. J Anesth 2016;30(5):884-90. (PMID:27376823).

12. Calvani R, Miccheli A, Landi F, et al. Current nutritional recommendations and novel dietary strategies to manage sarcopenia. J Frailty Aging 2013;2(1):38-53. (PMID:26082911).

13. Hernández-Socorro CR, Saavedra P, LópezFernández JC, Ruiz-Santana S. Assessment of muscle wasting in long-stay ICU Patients using a new ultrasound protocol. Nutrients 2018;10(12). pii: E1849. (PMID:30513718).

14. de Hoogt PA, Reisinger KW, Tegels JJW, Bosmans JWAM, Tijssen F, Stoot JHMB. Functional Compromise Cohort Study (FCCS): Sarcopenia is a Strong Predictor of Mortality in the Intensive Care Unit. World J Surg 2018;42(6):1733-41. (PMID:29285609).

15. Fan E, Cheek F, Chlan L, et al. ATS Committee on ICU-acquired Weakness in Adults; American Thoracic Society. An official American Thoracic Society Clinical Practice guideline: the diagnosis of intensive care unit-acquired weakness in adults. Am J Respir Crit Care Med 2014;190(12):1437-46. (PMID:25496103). 